THE HISTORICAI, MEMORIAL AND ART DEPARTMENT OF IOWA

\author{
By Ray C. Stiles
}

The founder and first curator of this department of state, Charles Aldrich, as early as 1860, started the agitation of public opinion for the establishment of a State Historical Department, commemorative of the lives and issues of the Iowa pioneer. ${ }^{1}$

In the year 1884, Mr. Aldrich, feeling that some concrete act would add impetus to his dream for the state, presented to the trustees of the State Library a simple autograph collection, proposing it should be placed in the State Library and further additions to the collection made. This offer was accepted and eventually two cases were provided, but no one was willing to arrange the materials thus provided, therefore, Mr. Aldrich came to Des Moines" at his own expense, to care for the collection.

In 1888, the Twenty-second General Assembly provided $\$ 1,000$ to be expended for the care and preservation of objects in literature, art and science, which should be presented to the state." In 1890, a committee representing the Pioneer Lawmakers Association visited the Twenty-third General Assembly and secured an appropriation of $\$ 3,000$ to continue the collection of documents, papers, etc., "relating to the earlier days of our. Territory and State," under the direction and authority of the trustees of the State Library. Mr. Aldrich was appointed to do this work at an annual stipend of $\$ 1,200$ for the years 1890-91. No rooms were provided for the collections and space provided for the State Library was used. Governor Larrabee, in his biennial message to the 'Twenty-third General Assembly, had indicated his approval of a permanent Historical Department at the State House and Governor Boies also gave his approval to the plan in his biennial message in 1892 .

In the Twenty-fourth General Assembly, Colonel C. H. Gatch of Polk County introduced a bill in the senate providing for the establishment of a State Historical Department and providing

1 First Biemial Report of the Hist. Dept. of In., 1893.

27 bid., pp. vi, vil.

3lbid., p. vii.

${ }^{4}$ Acts of the T'uenty-third General Assembly, p. 93. 
that the original "Aldrich Collection" be a part thereof. This bill passed the Senate unanimously and with but little opposition in the House. The bill provided for a curator who should hold office for a term of six years to be appointed by the trustees of the Iowa State Iibrary who were to have the controlling and directing authority of the new department. The three lower southeast rooms in the capitol, originally designed for the State Historical Society, were assigned to the new department.

The board of trustees immediately appointed Mr. Aldrich curator, with B. F. Gue as assistant, and the rooms assigned were occupied on July 1, 1892," the date the act became effective.*

To Charles E. Aldrich belongs the major credit for the establishment of the Historical Department. However, in his first biennial report, he very generously states that the establishment of the department is due principally to the public spirited men and women hercafter named: "Governors Sherman, Larrabee, Boies, and Jackson; the judges of the Supreme Court, since 1884 ; the state senators and representatives of 1888,1890 and 1892 ; the Iowa press, with no exception: United States Senators Allison and Wilson; Representatives J. A. T. Hull; Hon. John A. Kasson; Hon. W. M. McFarland, secretary of state; Hon. Gilbert B. Pray, clerk of the Supreme Court; ex-Chief Justice George G. Wright, Hon. Messrs. C. F., J. S., and R. P. Clarkson, J. M. and J. R. Shaffer, S. G. Matson, R. B. Wyckoff, A. W. Harlan, Ed Wright, Lafe Young, Henry Stivers, J. J. Hamilton, T. S. and N. R. Parvin, H. W. Lathrop, I. F. Andrews, B. F. Gue, Hiram Price, Peter A. Dey, Dr. C. A. White, R. D. Kellogg, John Russell, S. H. M. Byers, Will I. Smith, Samuel MeNutt, Peter Melendy, Mrs. Martha C. Callanan, Ham \& Carver, Dubuque; C. S. Byrkit, deputy secretary of state, and Frank E. Landers, clerk of the Executive Council."

We of the present generation have no conception of the difficulties and obstacles met and surmounted by the founders of the department led by Mr. Aldrich in the two decades prior to the successful completion of their efforts.

Mr. Aldrich in his biennial report of 1893 , for the Historical Department, discussing the necessity for the department, and after making a showing that the State Historical Society, al-

5First Biennial Report of the Hiat. Dept. of $I a ., 1893$, p. viii.

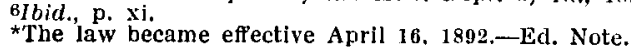


ready operating at Iowa City, in the nature of events, could not embrace the field contemplated for the Historical Department, says: "Meantime, the years were rolling by. The early settlers of the State were rapidly disappearing, either by death or removal to other regions, and all their recollections of pioneer times were fading away. .... No complete collection of our early. public documents was in existence, and but few of the pioneer newspapers had been preserved. Precious books, which will one of these days be worth their weight in gold, were so fading from public knowledge as in many cases to have become almost wholly forgotten. Our prehistoric pottery and stone implements were being gathered up and largely sent abroad to enrich the museums and collections of other states. Even the fossils secured by one of our geological surveys, and costly engraved plates for their illustrations-paid for by the Statemet the same fate. To see and study these fossils at this time necessitates a journey to an eastern city. .... While our statesmen upon the rostrum boasted the absence of illiteracy in Iowa, and pointed with pride to the magnificent record of Iowa soldiers during the great Civil War, it was continually pleaded that this State, free from debt, could not afford to collect the necessary data for her own history, nor preserve from waste the archaeological treasures yietded by her own soil, or even mementos of our early settlers and soldiers. It is a fact not to be proud ofa strange anomaly-that so many of the public documents published by State authority prior to 1860 are not now in the capitol nor represented in any collection. .... It is to stop this waste - to repair, as far as practicable, the losses which have already occurred, to build up collections incidental to such work, and contributing greatly to its usefulness and to the everyday instruction and enjoyment of the people, to save up precious materials which shall illustrate to future times the history of our own, that the efforts of the Historical Department have been devoted during the year and a half of its existence. That these are worthy ends no one, I believe, will at this day question."

Mr. Aldrich assumed the curatorship with his all-consuming energy and enthusiasm and outlined a definite program for the future. The need of a publication medium was immediately seen

Tlbid., pp. v, vi. 
and the curator, in January; 1893, was directed by the board of trustees to secure the copyright of the ANNals of Iowa and resume its publication. ${ }^{8}$ Thus originated the third series of the AnNals of Iowa as a quarterly magazine, appearing in its first issue for April, 1893.

The Annals or Iowa was first published by the State Historical Society at Iowa City in 1863 and discontinued publication in 1874. The Rev. Samuel S. Howe revived the publication in 1882 and discontinued it in 1884. No furtlier publications were undertaken until Mr. Aldrich revived it as the State Historical Department publication and since then it has had continuous quarterly publication except for the war years, October, 1915, to April, $1920 .^{\circ}$

The Ansals contributed to, largely by men and women most active and strong in the formative phases of building this state, as well as the editorial work of the founder, Charles Aldrich, and of Edgar Rubey Harlan, his successor, are of inestimable value to the research worker, historian or student of Iowa history.

It was soon realized that the quarters assigned by the Twentyfourth General Assembly would be entirely inadequate and a movement was instituted for legislative authority and appropriations for permanent quarters outside of the capitol building. As a result of these efforts the Twenty-sixth General Assembly appropriated $\$ 25,000$ to be used for the purchase of a site and erection of the Historical, Memorial and Art Building. The sum of $\$+, 300$ was expended to purchase the site on the east front of the capitol on the south corner of Capitol Avenue and Eleventh Street. ${ }^{10}$ Plans and estimates were submitted for the new structure and due to the meager amount available nothing further was done until the meeting of the Twenty-seventh General Assembly, which body appropriated an additional $\$ 30,000$ and authorized the abandonment of the site purchased. Authority was given the Executive Council to sell the building and lots formerly occupied by the Adjutant General's office on West Locust Street for the sum of $\$ 15,000$ and the proceeds used to purchase a new site for the Historical, Memorial and Art Build-

8Ibid., p. $\mathrm{x}$.

9See ANvass of Iowa, Series One; 'Two (Howe's Annals); 'Three.

10 AxNals uf Iowa, Vol. 3, p. 472. 
ing. The plat of ground north of Grand Avenue and west of Twelfth Street was purchased and building operations started for the west wing, that part of the building to be constructed for which appropriations had been made:

On May 17, 1899, Governor Leslie M. Shaw, using the same silver trowel used by Governor Samuel Merrill on November 23, 1871, to lay the capitol cornerstone, laid the cornerstone of the Historical, Memorial and Art Building with appropriate ceremonies." The completed wing was occupied by the Historical Department in installments between January 8, 1900, and March 15, 1900. The Thirtieth General Assembly on March 29, 1904, appropriated $\$ 200,000$ for the completion of the building.

The complete structure, costing $\$ 375,000$, is a handsome building of four full stories with 51,998 square feet of floor space. The exterior is constructed of LeGrand stone (Iowa öolite) from I.eGrand Township in Marshall County, Iowa. The exterior dimensions are 96 feet by 512 feet. The height from foundation to coping is 60 feet and to top of the dome 100 feet. ${ }^{12}$

Mr. Aldrich, with the load incident to housing and building lifted from his shoulders, was at last free to concentrate entirely on the extension of the scope of the department's activities and additions to its collections. It was his established thought and policy for the state to build up and fairly maintain a great Historical Museum, wherein should be secured as large collections as practicable in state and national history, literature, art, military relics and mementos, natural history, geology, archaeology, numismatics, etc.; it was to this end that his efforts and seemingly inexhaustible energies were dirceted.

The Aldrich antograph collection, at the time of his death had grown from a humble collection to one ranking with the world's finest. Mr. Aldrich fully realized the importance of the collection of Iowa newspaper files, and this work was one of the important activities inaugurated with the founding of the department.

The nucleus of our present Historical and Geneological Library was formed in the early years of the department and much stress has been placed by Mr. Aldrich on the importance and value of the pamphlet collection and its accessions.

11.Ibid., Vol. 4, p. 83 .

I2Ibid., Vol, 9, p. 232. 
The Historical Department from July 1, 1892, had been under the direct management of the curator responsible to the authority and direction of the board of trustees, who were also the trustees of the State Library. Its work had been peculiar to itself, unlike that of any other institution in the state. The Twenty-eighth General Assembly in 1900 passed an act (Chapter 114, Laws, 1900) providing for the consolidation of the State and Historical Libraries. This consolidation affected the management very materially as the two institutions were brought under one board of trustees and one directing head, the state librarian. Under the new order the Historical Department with the various branches was made a division of the State Library and bore the same relation to the State Library that the law, traveling and general reading and reference libraries bore to each other and to the State Library. Contrary to the curator's anticipations this change in the management of the Historical Department made no inroads, in fact, on the policies or authority of the curator as the state librarian never exercised the power granted him other than required legally, etc., for the support of the department.

On March 8, 1908, occurred the death of Charles Aldrich, the founder and curator of the Historical Department. His body lay in state in the rotunda of the Historical Building from 10:00 a. $\mathrm{m}$. to 2:00 p. m. on March 11, 1908, where memorial ceremonies were conducted. The tributes paid to him then demonstrated the high and permanent place he held in public esteem as a soldier, patriot, scholar and citizen. His marble bust today occupies its niche in the Historical, Memorial and Art Building of Iowa.

Edgar Rubey Harlan, assistant curator to Mr. Aldrich, since the spring of 1907, was named acting curator March 14, 1907, by the board of trustees and was appointed curator on October 1, 1909. ${ }^{13}$ Mr. Harlan came to the Historical Department from Keosauqua in Van Buren County where from 1899 to 1902 he had served as county attorney and subsequently as a member of the law firm of Work, Brown and Harlan. The new curator possessing a keen, analytical mind was peculiarly fitted by early environment, education and a remarkable capacity for concen-

I3Ibid., Vol. 9, p. 233. 
tration and hard work, for the responsibility placed on his shoulders to maintain the high standard, the traditions and accomplishments of his predecessor, Charles Aldrich.

That the foundation thus left to Mr. Harlan to build from was a challenge and a test of the best, no one today will deny and that the results are commensurate with the vision of its founder and stand as a live monument to these two men, its founder and later builder, the record proves.

The curator, seeing that a more efficient administration of the department could be obtained by a divisional arrangement of the department's functions, proceeded, with the approval of the board of trustees, to the physical classification by divisions and a:more literal organization of the department's activities, with divisional head and personnel; specialists in their field, but subject to the direction and authority of the curator.

The curatorship retained those functions, properties and activities which seemed least appropriately to fall within definite divisions and wherever, for want of sufficient support, a division head was dropped from the staff, his duties reverted to the curator. The divisions created by the reorganization of the department and additions as the work progressed and warranted it, were: General Division, Library Division, Archives Division, Museum Division, Annals of Iowa Division, Newspaper Division, and Iowa in World War Division.

A high standard was set and has been maintained for each of the divisions of the department, notably a museum illustrative of Mississippi Valley life, in which may be found specimens of natural history and prehistoric archaeology; relic, weapon, trophy, print and parchment touching periods and personages of note; manuscript, portrait and statue of Iowa men and women of honor and achievement; utensil, fabric, tool and other aids to the study of processes past and passing. This collection, carefully authenticated and labeled and displayed in a way most easily seen and understood, forms the great institution for popular museum education in the state.

The library is not a general library, but is devoted to such special subjects as early western history; the North American Indians; the Civil War, particularly regimental histories, publications of historical societies and kindred institutions. While- 
additions are constantly being made in all these departments, particular attention is given to the collection of Iowa publications and Iowa history and genealogical material. In the latter class are included general genealogical works, books on heraldry, separate family histories, histories of towns and counties of the older eastern states, colonial and revolutionary records, vital statistics, etc. A section called the "Iowa Authors' Collection" is composed altogether of the writings of Iowa authors and contains about 3,895 books and pamphlets. ${ }^{14}$

The Indian section of the library has a subject catalogue of great convenience to the research worker; books of early travel and exploration, angmented by a fine collection of maps and guide books; biographies of men who have touched the interests of Iowa; reports from early date of state institutions and departments; early college and university catalogues; conference records of religious denominations of Iowa and the pamphlet collection started by Charles Aldrich. An outstanding activity is the genealogical section with its collections of family history, county histories and state records of states from which the ancestors of Iowa men and women emigrated. In this library may be found a collection of English and Old World Bibles dating. back to 1635 and before, together with the Harrison or Van Meter family Bible that has been pierced by an Indian spear with the bloody footprint of the savage thereon where lie had placed his foot to withdraw the weapon.

The newspaper division has grown from its small collection of papers in 1892 to its present collection of over 11,000 bound volumes, and many more ready for the binder, of Iowa daily and weekly newspapers. $A$ complete file of bound volumes of the New York Herald 1848 to 1914 and the Neze York Times from 1914 to 1922, with index, are to be found in this division. The Iowa legislature has required that at least two papers from cach county be preserved, and at the present time 237 weekly county papers and 33 dailies are received. The value of this collection to the student of Iowa history cannot be measurcd carelessly, as accurate historical data may be secured from these files that it is impossible to secure from any other source.

The oldest paper on file is an issuc of the Boston Chronicle

14.July 1,1936 , the library contained 30,155 books and pamphlets. 
of 1768. A few other papers on file are over 100 years old. An incomplete file for two ycars of the Dubuque Visitor, the first newspaper published on Iowa soil, from May, 1836, to June, 1838 , is in the collection. 'This collection, considered by the department as its most valuable source of historical data and information, is readily accessible and is constantly used by persons from all walks of life.

The curator, with the advent of the World War, organized the Iowa in World War Division, shaping the future policy of the department to include not only relics, uniforms, weapons, medals, citations, documents, biographies, and portraits and other objects illustrative of the service of Iowa men and women who served in the common cause of humanity, but to also record the post-war achievements of these men and women in civil life.

The division is full of interesting memorabilia of the men and women who lost their lives in the service of their country; however, the collection of portraits of the men and women who made the supreme sacrifice, either by disease or on the battle front, arranged by the ninety-nine counties of the state with each county represented, receives the most attention from the general public. In each instance the name, rank in service, organization and nature of death is recorded with the portrait or photograph.

Ranking next, perhaps, in general interest to the public are the collections of medals of the United States, sur allies and the hostile nations, then comes the Kerwin collection of French, Russian, Polish, Italian, German, and British World War posters.

The Public Archives Division of the department, a pioneer in this work in the field of the states, houses over $12,000,000$ documents and 40,000 bound records of the state's business dating back to territorial days and up to date. A complete record of the vital statistics of the peoples of Iowa so far as they were recorded from 1880 to present date are on file in this office. Certified copies of these records are made on certificate of the curator, whose certification has the same legal cffect as did the certification of the original state officer, commission or department head. 'The gradually increasing importance of this division to the people of the state is shown by the fact that in the year 
1926, the calls on the division for information or certified copies was 3,276 , while in 1935 it rose to over 10,000 .

The Iowa Hall of Public Archives has descrvedly attained an international reputation in its ficld, so much so, that many states of the Union, when establishing a Hall of Public Archires; have adopted the Iowa plans, policics and methods devised and in use there.

The preliminary archives organization was authorized by legislative enactment in 1906 by the Thirty-first General Assembly, and its scope and permanent organization completed by authority of the Thirty-second and subsequent general assembly. From an administrative standpoint, the value of the division is of unquestioned value and to the student of Iowa history, research worker or historian its files are invaluable.

The General Division has those functions appertaining to exccutive and administrative duties. All accessions are clearcd through this division, catalogued and assigned to the departmental divisions for custody and care. 'The art phase of the department work, such as sculpture, oil portraits, photographs, the J. N. Darling cartoons, the memorials-the Aldrich autograph collection, the private and personal papers and manuscripts of Iowa citizens, many of them of national repute, are displayed and administered by this division.

The curator, realizing that some incthodical system should be instituted to regulate the haphazard course through the department's facilities by student groups, study clubs and others, inaugurated a systematic plan of departmental facilities study, and assigned the administration of the plan to this division. This plan has greatly increased the usability and value of the department to these groups and the general public.

The State Historical Department of Iowa, the legal designation of the department since its founding in 1892, was changed by final enactment of the Forticth Extra General Assembly ${ }^{15}$ to the Historical, Memorial and Art Department of Iowa, the legal status to be effective coincident to the publication of the Iowa Code of 1924. The effect of the act was to separate the State Library and the Historical Department into two distinct institutions, whereas, from 1906 until the action of the Forticth I5ANNAl.s or Iowa, Vol. 14, p. 382; see also Twenty-third Biennial Report of
the Hist., Mem. and Art Dept. of Ia., 1034-1930, p. 5. 
Extra General Assembly, the Historical Department had simply been a division of the State Library subject to the nominal direction of the state librarian. The curator under the new authority granted is responsible only to the board of trustees, which is composed of the governor, secretary of state, superintendent of public instruction and the nine Supreme Court judges.

In conclusion it seems worth while to say that this fine institution with its many and varied facilities and collections, freely available to the historian, research worker, student of Iowa history and the general public, invaluable to posterity, is today accepted in a matter of fact spirit by many of the citizens of Iowa and faces the same apatly on the part of our legislators for support both financial and moral, as was encountered by its founders in the three decades prior to the first legislative enactment authorizing the establishment of the State Historical Department of Iowa.

\section{A MONUMENT TO ALDRICH}

The Iowa historical building, whose corner stone was laid this. afternoon, will be a perpetual monument to Mr. Charles Aldrich. It is eminently proper it should be so. He conceived the idea, projected the plans and pressed to fruition in stone and steel this great work. Just fifteen years ago this month a conference was held between Mr. Joseph Beck, of the supreme court of Iowa, and.Mr. Aldrich in which the latter offered to donate to the state his private historical collection as a nucleus for a future state museum of art, literature and history. It was the one thing which the new state capitol just completed and occupied, lacked.... While in a greater measure the people of the whole state should be congratulated, it is fitting that to him personally, on this occasion, there should be given assuranec of appreciation.-I'he Daily Gate City, Keokuk, Iowa, May 18, 1899. (In the Newspaper Division of the Historical, Memorial and Art Department of Iowa.). 
Copyright of Annals of Iowa is the property of State of Iowa, by \& through the State Historical Society of Iowa and its content may not be copied or emailed to multiple sites or posted to a listserv without the copyright holder's express written permission. However, users may print, download, or email articles for individual use. 